\title{
3.ノンリニア編集・送出システムと 放送局における運用
}

\author{
正会員 岡 村 智 $之^{\dagger}$, 正会員上 田 博 唯 ${ }^{\dagger \dagger}$, \\ 正会員 浮分谷 文 雄 $^{+\dagger+}$
}

\section{1. ま え がき}

放送局におけるノンリニア編集・送出システムの運 用は，スタンドアローンでアナログコンポジットのビ デオ信号を入出力する形態から, ビデオサーバを設置 してノンリニア機器間をディジタル信号で接続するシ ステムへと変化をしている．放送局への導入を検討す る立場から，ノンリニア編集・送出システムとその運 用の問題点を検証してみた。

\section{2. 放送局におけるノンリニア編集システム の運用}

\section{1 運用の利点}

(1) ランダムアクセス

ノンリニア編集では, テープ編集のように実際に素 材を転写して時系列的に並べる必要がない. どの位置 に収録された素材にも均一にアクセスすることができ る. 使用する素材のスタート点のアドレスを指定すれ ば，そこからの再生が可能となる。カット編集であれ ば，実際にデー夕を書き換えることなく編集が行える ので,やり直しや細かいトリミングなどが容易とな る.これは，ノンリニア EDL(Edit Decision List) 編集とも呼ばれるべきもので, EDLを作成すれば実 際の映像をすべて見なくても編集が完成してしまう. しかし，編集者がいかに素材内容を把握しているとい っても，作品のプレビューなしには終了とはいえな

\footnotetext{
$†$ 株式会社フジテレビジョン 技術開発室企画開発部

† 日立電子株式会社 開発研究所

†† 日立電子株式会社 映像事業部

"Non-linear Editing/Transmission and Application in Broadcasting Station" by Tomoyuki Okamura (Planning \& Development Division, Enginerring Department, Fuji Television Network, Inc., Tokyo), Hirotada Ueda (Research \& Development Laboratory, Hitachi Denshi, Ltd., Tokyo) and Fumio Ukigaya (Broadcast \& Video Operations Division, Hitachi Denshi, Ltd., Tokyo)
}

い.また，ノンリニア編集においても，エフェクト加 工を伴う場合は新たに素材デー夕を生成せねばならな い.したがって，ノンリニア EDL 編集と実際に編集 ずみデー夕を作る編集の両方を組合せて実用的な編集 システムとなるので, これらのオペレーションをスム ーズにできる作業環境をサポートする必要がある.

（2）マルチプログラム作成

ニュース編集など時間に急な運用では，1つのカセ ットをジャグリングして使うことも多い。ノンリニア サーバは，大きいデー夕伝送レートを持つために，同 一素材に対して複数のクライアントが同時にアクセス することが可能である．原素材に限らず，編集の過程 で作られる中間的な素材も共有することが可能であ る. 1 つのテーマを 2 人の編集者が同時に編集するこ とや, 同一の素材から 2 つ違うテーマの作品を仕上 げる協調作業ができるようになる．ランダムアクセス 性によって, 同一素材の使い回しや, 瞬時のオンエア 素材の入れ替えなどが容易となる。ノンリニア機器 は, 従来のVTRカートマシンとスイッチャ, そして APC(Automatic Program Controler) のようなコン トロール機能，を合わせ持っているので放送システム の諸分野に応用することができる．

(3) 素材管理

ノンリニア編集システムでは素材管理が容易とな る. 従来, 素材情報の管理は, 映像信号を記録してい るテープとは別にバーコードやメモ用紙など他の記録 手段を使って行っていた．素材のディジタル化を前提 とするノンリニア編集システムでは, 素材と付加情報 を一体として扱うことができるので，ディスプレイ上 で素材情報の検索を行い, 物理的にテープを運ぶこと なしに素材にアクセスすることができる.アイコンを 用いることにより GUI(Graphic User Interface) を 用いたインタフェースが可能で，文字を読むことなし に直感的に目的の素材にアクセスすることが可能とな 
る.そして, 撮影や編集などの各段階での情報を一元 管理することができる。

（4）オペレータのノンキャリア化

テープでの編集は, 時系列の整理と編集データの作 成・変更に手間がかかり, 編集オペレー夕は熟練と経 験を要した。ノンリニア編集では，元素材，ワークテ ープといった区別がなく，元素材の管理もできるの で, 素材を消してしまう危険も少ない。リトライが自 由に可能なことから, ディレクタ自らの編集も可能と なり，実際のオンエア用の素材を使ったアンダスタデ イも並行して行うことができるため, 編集オペレータ の育成も容易となる。

\section{2 運用の問題点}

（1）画像圧縮の多段接続による画質劣化

ノンリニア機器は, 記録媒体としてハードディスク や光磁気ディスク, 半導体メモリーなどを用いる.こ れらは, テープに比べて時間当たりのコストが高い. これを低減するために画像データの圧縮技術が用いら れる. 圧縮方式としては, フレーム内圧縮の JPEG 準拠の方式と, フレーム相関をとる MPEG-2 準拠の 方式が一般的であるが, 同じ JPEG 準拠, MPEG 準 拠といっても，これらは異なるメーカ間で互換性がな いのが現状である．A社のシステムで圧縮したデー 夕を B 社のシステムでは再生することができず，い ったんベースバンドの映像信号に伸張した後, もう一 度圧縮して処理をする必要がある。この場合, 圧縮伸 張の多段接続による画像劣化が問題となる. 各々の圧 縮は, その方式に独自のクォリティの配分をしてお り,これが多段接続された場合, クォリティ劣化の度 合いの激しいところが生き残り，全体的にクォリティ が劣化することになる．これを防ぐためには，現在の ところ次の 3 つの手段しかない.

(1)できるだけ圧縮伸張を繰り返さないシステムを 設計すること。

(2) 同一の圧縮方式を採用すること.

(3)できるだけ圧縮による画像劣化の少い圧縮方式 を採用すること。

圧縮方式の規格統一に関しては，マルチメディア時 代を迎え, コンピュー夕業界からの参入などで放送機 器業界全体の枠組みが変化しつつあることもあり, 予 断を許さない.

（2）キャプチャリング時間

ノンリニア機器を導入しても, 素材の収録は現行の カムコーダやVTRで行われることが多い. その場 合, テープからディスクなどの記録装置に記録（キャ プチャリング）する作業が必要となる．この作業には
素材の実時間と同じ時間がかかる．テープ系の編集で は，中身さえわかっていればすぐに作業を始めること ができるが, この点ではノンリニアの方が時間がかか ることになる．伝送やプレビューと同時にキャプチャ リングを行う方法や, プレビューをしながら必要箇所 だけをキャプチャして記録容量を少なくするなどの工 夫がされている。

（3）ディスプレイ上での素材アクセス

オペレータが素材をどう認識するかという点が大き な問題である.今までは物理的なカセットとラベル， そして物理空間に配置された場所によって認識するこ とができた。この方法は一覧性があり, 経験豊富な編 集マンがオペレーションする環境の中では効率的なシ ステムであった。ノンリニア媒体上に記録された素材 は，人間が直接見ることができないので，検索ツール を必要とする。表形式になったものや，映像信号から 作ったアイコンをべースにして素材を認識する場合が 多い.これらもコンピュータが使っているヒューマン インタフェースをそのまま移植したという段階であ り，テレビ制作者が培ってきた文化といかに融合させ るかが今後の課題である。

\section{3 ノンリニア編集システムの導入と運用の変化}

（1）時系列に支配されたシリーズ作業からパラレ ル作業へ

従来のテレビ制作は, 出来上がり作品の時系列に従 って作業が進んでいた．特にニュースなどのオンライ ン編集では素材の到着がまちまちであり，シーン 2 の 素材が到着していてもシーン 1 の素材が未着の場合, 編集に入れない場合がある。また，物理的なテープの 制約から，複数の編集者が同時に 1 つの作品の作業を 並行して行うことも困難であった。ノンリニア編集・ 送出システムを用いると, 同時並行的に作業を進める ことができる。これは，コンピュータで 1 つの CPU を使って作業をしていた環境から，複数の CPUを使 ったマルチタスク処理のできる作業環境に変わるのに よく似ている．従来のシステムは, ピークとオフピー クの差が非常に激しい運用環境では，ピークに対応し た機器を用意しなければならなかった。ノンリニアシ ステムでは, リソースを共有することによりピーク時 に対応できるフレキシブルなシステムの構築が可能と なる. 撮影取材, 素材プレビュー, 粗編集, 編集, 完 成品プレビューといつた過程の順番を変え, あるいは 同時並行して行うことができるようになり，テレビ制 作者にも, 新しい制作スタイルの確立が求められてい る.

（2）制作情報と素材の結合による作業環境の変化 
ノンリニア編集・送出システムでは, 素材と情報を いっしょに取り扱い, 例えば $\mathrm{CM}$ 素材に内容, バー ジョン, オンエア日時, 期限などの付加ができる.ネ ットワークを活用して情報と素材を共有することによ り, 時間や空間の壁を超えた共同作業も可能となる. イマジネーションをかき立てる情報を, より多くの人 に提供できるわけである.

\section{3. 放送用ノンリニア送出システム}

\section{1 ニュース用ビデオサーバ}

（1）ニュース用ビデオサーバの特徴

ニュース素材は素材尺はまちまちで数が多く, 取材 対象によって様々の運用形態があるため, 他の番組制 作とは違った多機能化が求められる.

ニュース用ビデオサーバに求められる機能を以下に まとめる.

(1) 大量の素材量を扱えること.

(2) ピークとオフの差が激しく, 一時に集中する運 用に耐えること。

(3) 素材を収録した瞬間から使える、いわゆる録つ て出し編集ができること.

(4) 入出力のポート数が多いこと.

(5) ファイル記録の形式がオープンエンドに対応で きること.

(6) 報道用アーカイブとの親和性が良いこと．

(7) テープに比べてリーズナブルな初期コストとラ ンニングコストであること.

上記を勘案すると理想的なサーバは, 大容量で入出 力ポートが多数あり, 自由なランダムアクセスが可能 なものということになる. 現時点では, このようなサ 一バは存在したとしても非常に高価なものになってし まう。

そこで, 現実的なシステムとして以下のような構成 が考えられている。

（a） 1 次素材を記録するサーバと送出サーバを分 離する。

（b）報道素材へのアクセスは日を追うごとに少な くなるので, 1 次サーバと 2 次サーバに分離す る。

モデル図を図 1 に示す.

このようにして大規模なサーバシステムを構築する ことができるが, 規模によってはそれぞれのサーバを 統合した方が良い場合もある。

（2）ニュース用サーバの実例

我が国では平成 7 年に宮城テレビ放送と東京メトロ ポリタンテレビジョンの 2 局が, ビデオサーバを使っ

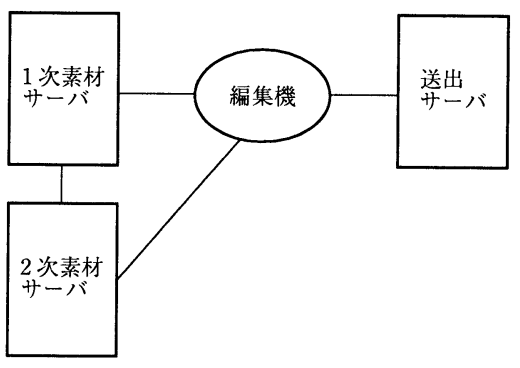

図 1 現実的なビデオサーバの構築例

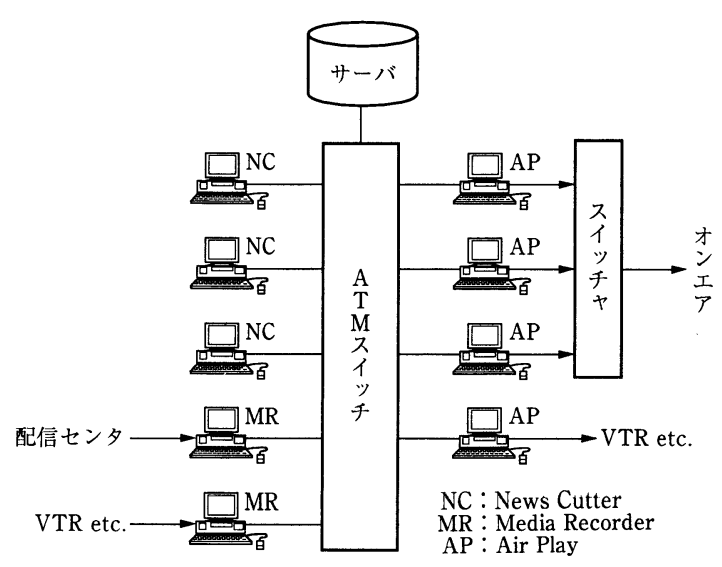

図 2 ニュース用ノンリニア編集・送出システムの構 成例

て直接放送するシステムを採用した。これらの局では 主としてニュース番組の制作・放送に利用している。 また，システム構成はおおむね図 2 のようになってい る.

メディアレコーダ $(\mathrm{MR}$, 含 $\mathrm{A} / \mathrm{D}$ 圧縮エンコーダ $)$, ニュースカッタ ( $\mathrm{NC}$, 含 $\mathrm{A} / \mathrm{D}$ 圧縮エンコーダ $)$, エアープレイ (AP, 含 $\mathrm{D} / \mathrm{A}$ 伸張デコーダ) と呼ばれ る 3 種類のクライアントが, それぞれ複数台, ATM スイッチを介してサーバに接続される. MR は配信セ ン夕, 回線セン夕から送られてくる。あるいはVTR から供給される映像・音声をリアルタイムでディジ夕 ル圧縮してサーバに書込む働きをする，NC はサーバ の中にある映像・音声を取り出してノンリニア編集 し, サーバに書戻す役割を果たす．AP は放送スケジ ュールとして与えられるプレイリストに従って, サー バから映像・音声を順次読出して伸張し, オンエア部 に送り出す. AP はVTRへの収録, プレビュー, 回 線への出力等の目的にも利用される. またプレビュー に関しては MR, NCもその機能を有している.

編集をフレーム単位で行うために, フレーム間相関 を使わない JPEG 圧縮が, $5: 1$ 程度 $(30 \mathrm{Mb} / \mathrm{s}$ 程度) 
のデータレートで利用される。サーバのファイル容量 は, 数百ギガバイト(数十時間分)から 1 ララバイト強 (百時間分)に達する. システム中の各クライアントの 数は, 上述の機能とシステムの運用目的, 放送局の規 模, 人員等を勘案して決められる.MR は 2 台程度, $\mathrm{NC}$ は数〜十数台, AP は数台というのが現状の選択 範囲となっている. クライアント同時動作可能数は, サーバの能力, ATM スイッチの能力, クライアント 上で行う処理の内容，そしてシステムパラメータのチ ューニングなどによって決まるが，現状では 7 台前後 が上限のようである。

今後の方向としては, ハードディスクの高密度化, 高画質・高圧縮率の追及が行われ，より小さなスペー スで充分な容量のサーバが実現されよう。そして，同 時アクセス数を増大する方式などの開発により, 多様 なニーズに応えられるようになる，そうなれば，取材 から編集，オンエア，そしてアーカイブまでの過程で 生じる, 映像・音声・文字・数值といったあらゆる情 報をネットワークで一元管理できる新しい運用形態が 急速に進展すると考元られる。

\section{2 「録って出し」送出システム}

ノンリニア機器では, 終わりの確定していない素材 を収録しながら必要なカットを編集送出する，いわゆ る「録って出し」をすることが容易にできる．

記者会見が放送予定時間より 1,2 分早く始まった 場合, 開始時間を放送時間に合わせたり， $\mathrm{CM}$ 中のゴ ールシーンなどを無理なくつなげることが可能とな る. 特にスポーツ番組では従来, バレーボールやテニ スなどセット制で延長があるものなどは, 複数の VTR を並べて対応していた. 次のセットの展開によ っては現在放送しているセットの内容を変える必要が あるので，時間計算を行いながら録画しているVTR を再生に切り替えるといった複雑な操作が必要であっ た。これをノンリニア化すれば，素材尺の管理が容易 となり, 番組送出の自由度が増し, オン・ザ・フライ の送出が可能となる. また, 複数の映像を入力して, 裏カメラの映像やスロー再生, タイムリーで瞬間を逃 さないリプレイや, ハイライトシーンの送出が容易と なる。

\section{$3.3 \mathrm{CM}$ バンク}

$\mathrm{CM}$ 素材の送出に関しても, ノンリニア編集・送出 システムが応用されつつある。従来の CM バンクは, スポンサーから持ち込まれる複数のマザーテープをも とに, これらを送出順に並べ直すためのダビング作 業, いわゆる一本化を行う必要があった。このテープ の, 一本化作業後の送出順の変更は多大な作業を必要

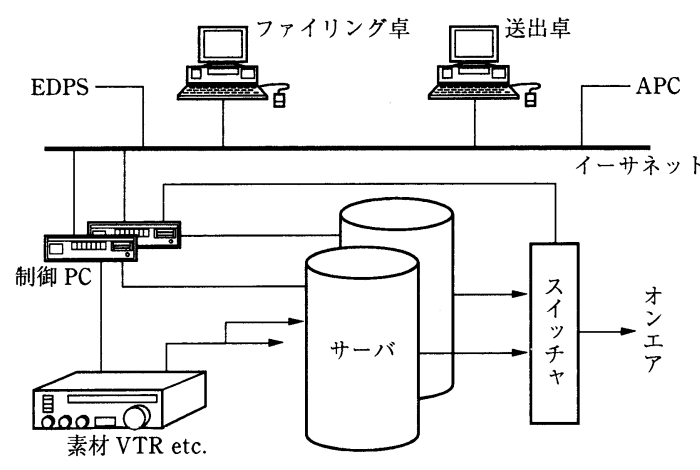

図 3 ノンリニア $\mathrm{CM}$ バンクのシステム構成例

とした。このため， $\mathrm{CM}$ 素材の受付を放送 3 日前(一 例)締め切らねばならないなど, 営業活動や番組編成 への制約になっていた。

これに対しノンリニアビデオサーバでは，ランダム アクセスの特徵を生かして, 素材は自由な場所に格納 でき, 差し替えなども $\mathrm{CM}$ 進行デー夕の操作だけで 実行できるので, 各種の事態への対応をオンエア直前 まで柔軟に行うことができる. 近い将来には半導体メ モリーを用いた完全固体化ビデオサーバも実用的な価 格レンジに入ると考えられ，そうなれば機械系の故障 という問題からも開放される.

編集等の 2 次加工の必要のない $\mathrm{CM}$ バンクの場合 は, MPEG-2 の映像圧縮方式が有効である。編集ず みの素材を登録して送出するのが目的であるために， フレーム間相関を用いた高画質・高圧縮率を活用でき るという判断による. 実際, JPEG 方式の半分以下の $10 \sim 15 \mathrm{Mb} / \mathrm{s}$ のデータレートで実用的な画質が得られ る。

図 3 に, ノンリニア $\mathrm{CM}$ バンクのシステム構成の 概要を示す，サーバは多数のハードディスクが RAID という方式で冗長性をもって多重化されているので, 一部のディスクが故障しても問題なく動作を継続でき る.さらにハードディスクは電源を切らずに差し替え 可能な構成となっているので, 問題を生じたディスク の交換なども，システムを停止せず，運用を続けなが らメンテナンスすることができる。さらに, 制御 PC とサーバが二重化されており，ハードディスク以外の 障害が発生した場合にも, 予備側に切り替えることで 運用は維持される。

ノンリニア $\mathrm{CM}$ バンクはコンピュータ主体のシス テムであるため, 従来なかったような機能を実現し統 合化することも容易である。例えば，CM 素材を登録 すると同時に，コンピュータの画像認識機能を動作さ せてシーンの変化点を検出することができる。この変 
化点ごとのフレーム画像は, ファィリング卓のハード ディスク上に記録され，イーサネットを介して共有さ れるので, すべての卓において $\mathrm{CM}$ 素材を代表画像 の並びとしてビジュアルに一覧表示することができ る。この機能を活用することにより, 各卓におけるオ ペレーションを誤操作の起きにくい安全なものとする ことができ, プレビュー目的の多くを, より素早いも のへと代替することもできる．

\section{4. むす び}

ノンリニア編集・送出システムは, 編集だけにとど まらず映像制作全体に影響を及ぼしていくと考えられ る. 画像を圧縮して処理することによりコンピュータ で処理が可能となった. 今後, 圧縮技術の進歩により 高圧縮の画像でも画質のクォリティが向上し, CPU の高性能化や記録装置の低廉化により非圧縮でのノン リニアも実用となる.サーバから直接読出して送出を するような, スイッチャを用いない APC の構築も考 えられる. CM の配信もサーバに直接送り込むことに なる. 各社のサーバがネットワーク接続されることに より，遠くにある映像素材も瞬時に利用できるように なる。
映像制作から 2 次分配に至るまでのトータルディジ タル化の流れの中で, 制作システムがコンピュータ技 術を生かしたディジタル化へ進み始めたといえる。

(1996 年 5 月 30 日受付)

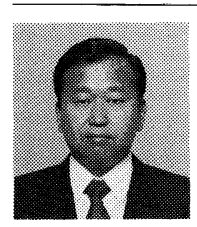

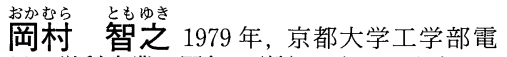
子工学科卒業. 同年, (株)フジテレビジョン に入社. 放送技術センター，製作技術センタ 一を経て，現在，技術局企画開発部にて，， ンリニア報道制作システムおよび次世代放送 システムの開発を担当. 正会員.

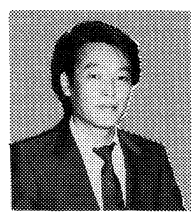

上总博唯 1973 年, 大阪大学大学院 工・通信修士課程修了. 同年, (株) 日立製作 所中央研究所入社. 画像処理 - 認識技術, 、 ルチメディアシステム; ヒューマンインタフ エース等の開発に従事. 1994 年より, 日立 電子 (株) 開発研究所第三研究部部長. ソンリ ニア映像システムの開発を担当. 工学博士. 正会員.

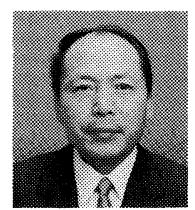

浮がや点み扔

浮ヶ谷文雄 1975 年, 東京電機大学大学 院博士課程修了. 同年, 日立電子(株) に入 社. 回路設計用 CAD の研究, 放送用カラー カメラの開発・設計に従事. 現在, 同社映像 事業部次長. 工学博士. 正会員. 